日消外会誌 $13(7): 863 \sim 867,1980$ 年

\title{
非絞扼性腸閉塞症に抢ける胆汁酸代謝
}

\author{
横浜市立大学第 2 外科 \\ 石黒 直樹 福島 恒男 久保章 \\ 川本勝仲野 明 土屋 周二
}

\section{BILE ACID METABOLISM IN NON-STRANGULATED INTESTINAL OBSTRUCTION}

\section{Naoki ISHIGURO, Tsuneo FUKUSHIMA, Akira KUBO, Masaru KAWAMOTO, Akira NAKANO and Shuji TSUCHIYA}

Second Department of Surgery, Yokohama City University School of Medicine, Yokohama

非絞扼性腸閉塞症42例の腸液中の胆汁酸分析を行った，粉胆汁酸濃度は減少し，抱合胆汁酸 $\mathrm{G} / \mathrm{T}$ 比は 低下した，腸内細菌の增殖が認められ，遊離胆汁酸の検出率は増加した．胆汁酸分画では deoxychol 酸が 減少した.

治療後には $\mathrm{G} / \mathrm{T}$ 比は上昇し, 腸内細菌は減少した。しかし, 総胆汁酸濃度, 胆汁酸分画組成比, 遊離 胆汁酸検出率は，手術的治療後には改善がみられたが，非手術的治療では改善が認められなかった。

胆汁酸には腸管における水分, 電解質の吸収を阻害する作用のあることが報告されて招り, 腸閉塞時に は腸管内の液体貯留の一因となっていると考光られた。

案引用語 : 腸閉塞症, 胆汁酸, deoxychol 酸

\section{はじめに}

腸閉塞症の病態生理に関しては数多くの報告が見られ るが，その大部分は腸閉塞症に伴うショックの原因ない しその死因に関するるのである. 本邦では松倉 ${ }^{1)}$ が腸閉 塞時の有力な chemical mediator の1つとしてアセチル コリン説を提唱している. 松倉 ${ }^{1)}$ ，恩田 ${ }^{2}$ らはその立場 から腸閉塞時の胆汁酸の作用について，1．抗アレル ギー作用がある．2．腸管組織中のア七チルコリンの血 中への移行を阻止抑制し, 腸閉塞動物の生存時間を延長 させる．3，腸内細菌, 特に大腸菌群の腹水中への移行 と, その菌体成分エンドトキシンや菌体核酸 DNA 分画 などの高分子物質の血中ならびに腹水中への移行を阻止 抑制する.などの報告をしている。しかしながら，これ らの成績は in vitro あるいは胆汁酸を腸管内に流下さ せた際のもので, 腸閉塞症例における腸管内の䏣汁酸濃 度やその組成比の 経時的変動に関する研究はみられな い.

今回著者らは，手術的あるいは非手術的に治療した腸
閉塞症例の治療前後における腸液中の胆汁酸を薄層およ びガスクロマトグラフィー法で分離測定し，その変動に ついて検討を加えたので報告する.

\section{対象}

昭和 51 年から 54 年までに横浜市立大学病院第 2 外科に 入院した非絞拒性腸閉塞症42例を対象とし, 手術例, 非 手術例に分けて検討した. 手術例は22例で, 男性19例, 女性 3 例であり, 閉塞部位は, 回腸 16 例, 空腸 5 例, 結 腸 1 例であった. 手術々式は, 閉塞部解除 16 例（回腸 12 例, 空腸 4 例), 空腸空腸吻合 2 例, 回腸部分切除, 空 腸部分切除, 閉鎖孔へル $=7$ 嵌頓解除, $\mathrm{S}$ 状結腸人工肛 門造設各 1 例であった. 非手術例は20例で, 男性15例, 女性 5 例であり, 閉塞部位は, 回腸 13 例, 空腸 7 例であ った，保存的療法としてイレウス管あるいは胃管を用い て消化管の減圧を計った.

\section{方 法}

検体は挿入したイレウス管また胃管より採取した腸液 を用いた。手術例ではさらに術中閉塞上部腸管を穿刺し 
て腸液を採取した。

1. 胆汁酸分析

抱合胆汁酸および遊離胆汁酸の分析は，Gänshirt ら の方法にしたがって薄層クロマトグラフィー法を用い た. 腸液 5 10ml を約10倍量の ethanol で抽出し濾過 したものを減圧乾固し, methanol $2.0 \mathrm{ml}$ に溶解し試 料とした. 薄層プレートは Kieselgel 60を用いた。抱 合胆汁酸の展開には Gänshirt らの solvent system II (n-butanol : 水酢酸：水=10:1:1）を用いた、 ヨード ガスを用いて発色させたスポットを搔き取り $65 \%$ 硫酸 $4.0 \mathrm{ml}$ を加えて $60^{\circ} \mathrm{C} て ゙ 60$ 分間加温発色させた. 遠心分離 後上清を波長 $386 \mathrm{~m} \mu$ で吸光係数を測定し，検量線より 各胆汁酸含有量を求めた. 本法では dihydroxy 胆汁酸を 分離できないのでこれを chenodeoxychol 酸として扱っ た. 結果は抱合胆汁酸 Glycine/Taurine 比（以下 G/T 比）として表わした，遊離胆汁酸の展開には，Hofmann ら")の solvent system I (acetic acid: $\mathrm{CCl}_{4}$ : di-isopropyl ether : isoamyl acetate : n-propanol : $\mathrm{C}_{6} \mathrm{H}_{6}=1: 4: 6$ : $8: 2: 2)$ を用いた. 遊離胆汁酸はスポットの有無を定 性的に検索した。

胆汁酸分画の分析は，ガスクロマトグラフィー法5)を 用いた. 腸液 $0.2 \mathrm{ml}$ に20倍量の ethanol を加え24時間 後に遠心分離した. この上清1.0〜2.0ml に $1 \mathrm{~N} \mathrm{NaOH}$ 水溶液 $4.0 \mathrm{ml}$ を加之, hexan で中性 sterol を除去し, $120^{\circ} \mathrm{C}$ で 4 時間加水分解した. $6 \mathrm{~N} \mathrm{HCl}$ を加えて $\mathrm{pH}$ を 約1.0とし ethylether で胆汁酸を抽出した. 内部標 準物質として cholan 酸を用いた. methylesther 化は diazomethan を用い, trimethylsilyl 化は TMS-HT (東 京化成）を用いた，装置は島律 GC-4CM 型ガスクロマ トグラフ, 検出器は FID を用いた. カラムは poly I 110/chromosorb W-HP (80〜100mesh) を充填した内径 $3 \mathrm{~mm}$, 長さ $2 \mathrm{~m}$ のガラスカラムを用いた. 試料注入部お

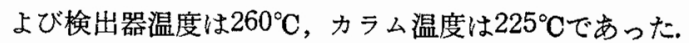

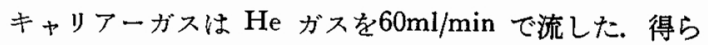
れたガスクロマトグラムより, cholan 酸の peak 面積に 対する各 peak 面積の比を算出し, 検量線を用いて各胆 汁酸の含有量を求めた.

2. 細菌検査

好気性菌は DHL 培地あるいは血液寒天培地を用い, 嫌気性菌は Gam 寒天培地を用いて分離同定した。

成

1. 抱合胆汁酸 $G / T$ 比の変化 (図 1 )

腸閉塞症例の腸液中 $の$ 抱合胆汁酸 $\mathrm{G} / \mathrm{T}$ 比は, 手術
図 1 腸閉塞症における抱合胆汁酸 $\mathrm{G} / \mathrm{T}$ 比の変化

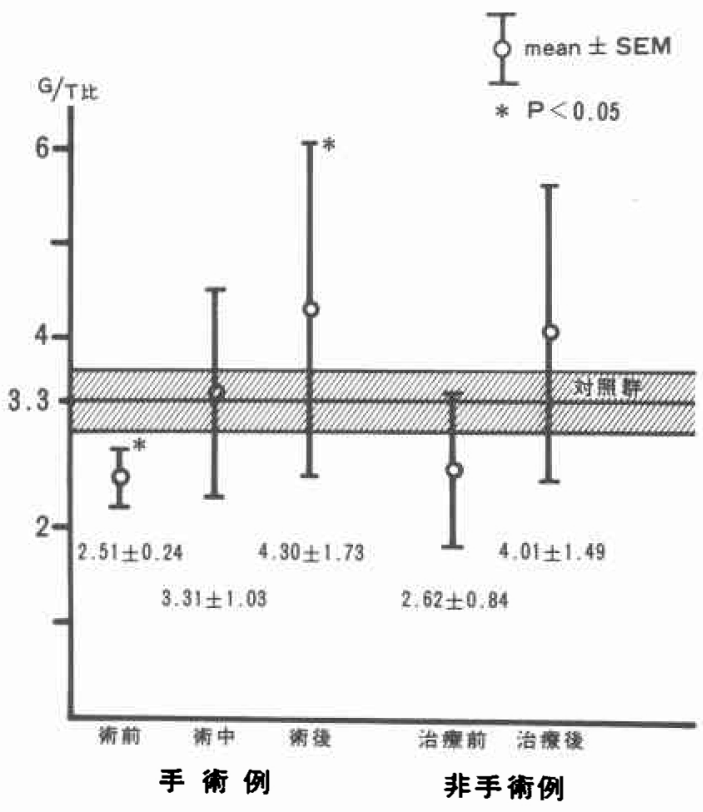

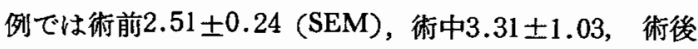
$4.03 \pm 1.73$ であり, 非手術例では治療前 $2.62 \pm 0.84$, 治 療後4.01土1.49であった. 腸閉塞症例の G/T 比は, 対 照群の胆襄胆汁の $\mathrm{G} / \mathrm{T}$ 比 $3.32 \pm 0.33(\mathrm{n}=15)$ と比べて 低下しており, 治療後には手術例も非手術例も上昇した. とくに手術例に和いて術前から術後への G/T 比の上昇 は統計学的にも有意であった $(\mathrm{p}<0.05)$.

2. 遊離胆汁酸検出率の変化（図2）

腸液中の遊離胆汁酸は，手術例では術前，術中とも44 \%の症例に検出されたが，術後は減少し $9 \%$ 症例にの み検出されたた。非手術例では，治療前 $73 \%$ 症例に検 出され，手術例に比べて高い検出率を呈 L，治療後も69 \%とわずかに減少しただけであった。

3. 総胆汗酸濃度の变化 (図 3 )

総胆汁酸濃度は，手術例では術前 $1.99 \pm 0.33 \mathrm{mg} / \mathrm{ml}$, 術中 $0.71 \pm 0.23 \mathrm{mg} / \mathrm{ml}$, 術後 $6.31 \pm 0.49 \mathrm{mg} / \mathrm{ml}$ であり, 非手術例では治療前 $1.09 \pm 0.16 \mathrm{mg} / \mathrm{ml}$, 治療後 $0.78 \pm$ $0.43 \mathrm{mg} / \mathrm{ml}$ であった. 腸閉塞症例の腸液中の 総胆汁酸 濃度は著明に減少するが，手術例では術後に急速な改善 がみられ。

\section{4. 胆汁酸分画の変化 (図 4)}

腸閉塞症例の 腸液中の 胆汁酸分画の 組成比を対照群 (胆嚄胆汁) の組成比 chol 酸 $37.3 \%$, deoxychol 酸 23.8 
図 2 腸閉塞症における遊離胆汁酸検出率の変化

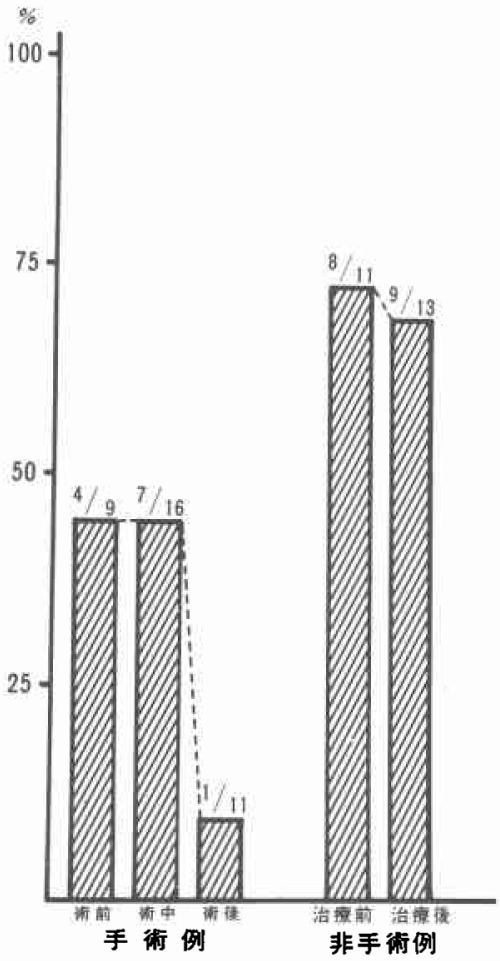

図 3 腸閉塞症における総胆汁酸濃度の変化

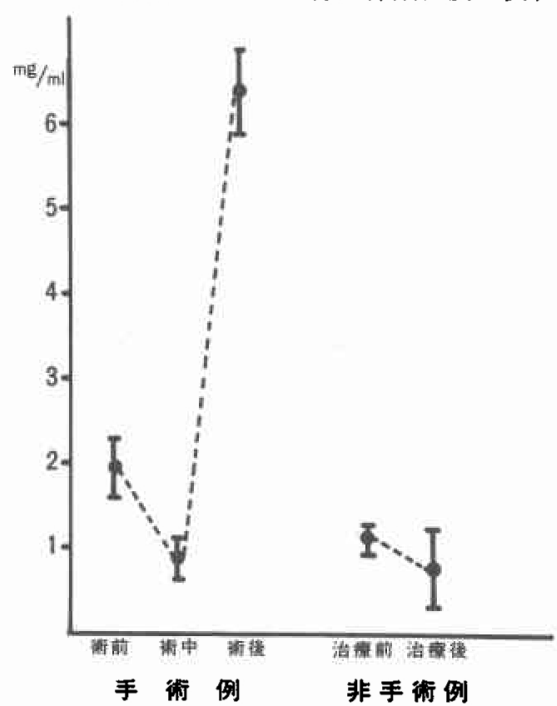

$\%$, chenodeoxychol 酸 $34.8 \%$, lithochol 酸 $1.4 \%$, ursodeoxychol 酸 $2.6 \%$ と比較すると, 手術例では, 術前は deoxychol 酸が9.2\%と減少し, chol 酸と chenodeoxy-
図 4 䦪閉塞症における胆汁酸分画の変化

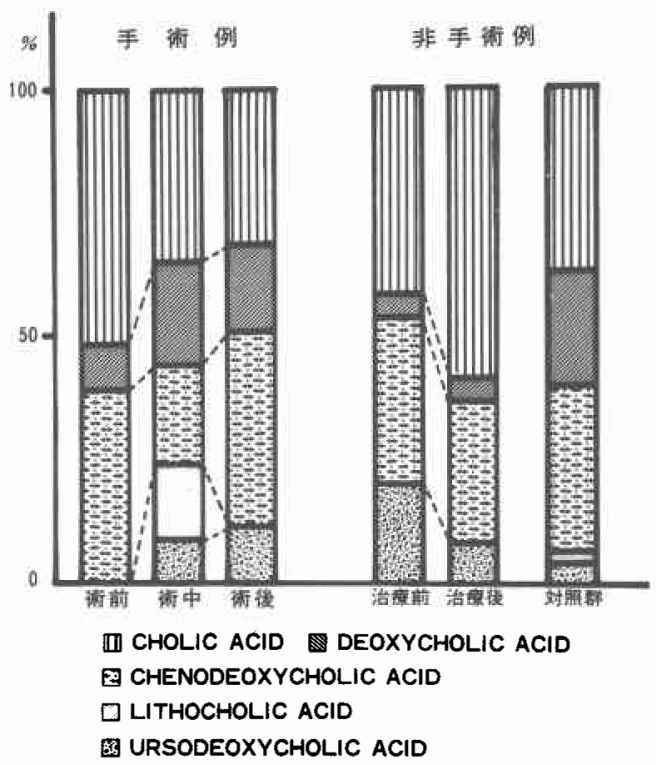

chol 酸が主体の構成をしていた. 術中は術前と比ぺて deoxychol 酸と lithochol 酸の増加が著明であった. 術 後の chol 酸. deoxychol 酸, chenodeoxychol 酸の組成 比は対照群のそれに近いものとなった。 一方非手術例で 屯治療前に deoxychol 酸は減少し chol 酸と chenodeoxychol 酸主体の構成していた. 治療後も deoxychol 酸 は減少したままで, chol 酸は增加した.

\section{5. 細菌検查成績}

手術例では，術前の腸液の $75 \%$ に $10^{5} \sim 10^{10} / \mathrm{ml}$ の. coli, Klebsiella, Enterococcus, Bacteroides などの細菌 さが検出されたが，術後には $20 \%$ に $10^{5} / \mathrm{ml}$ 以下と減少し た. 非手術例では，治療前の腸液の50\%に1 $10^{5} \sim 10^{7} / \mathrm{mI}$ の Enterobacter, Enterococcus, Klebsiella 等の細菌が検 出されたが, 治療後には $27 \%$ \% $10^{5} / \mathrm{ml}$ 以下と減少した.

\section{考 察}

胆汁酸は肝葴において cholesterol より生成されて胆 汁中に排泄され，通常その大部分が回腸末端で再吸収さ れ腸肝循環を営み，その特異な界面活性作用により腸管 に扎ける脂肪や脂溶珄ビタミン類の消化吸収に重要な役 割をはたしている。

腸閉塞症例では, 総胆汁酸濃度の 低下が著明であっ た. 腸管の閉塞により，閉塞上部の腸管に水分が貯留し これにより稀积され, さらに胆汁を含んだ呕吐やイレウ ス管による腸内容の吸引により胆汁酸の梂失が起り総胆 
汁酸濃度が低下したと考えられる，手術例の術中の腸液 は, 手術時まで臨床的改善がみられず，イレウス管より の吸引量も多く, 発症時よりさらに濃度の低下がみられ たと思われる. 治療後の総胆汁酸濃度の変化をみると, 手術例では改善したが，非手術例ではさらに低下した。 手術例では閉塞の解除により腸液により稀积されず, 胆 汁酸の腸肝循環む回復し, 総胆汁酸濃度は上昇したと考 えられる.これに反し非手術例で総胆汁酸濃度がさらに 低下したのは，臨床的な改善がみられた後でる胆汁酸代 謝に影響をおよぼす何らかの変化が残存しているためと 考えられる.

これらの総胆汁酸濃度の変化に伴う胆汁酸分画の組成 比の変化をみると, 腸閉塞症例では deoxychol 酸が減少 し, chol 酸と chenodeoxychol 酸優位の構成となってい た. 腸閉塞症例では前述のような過程で胆汁酸は变失し て腸肝循環が行われず, 肝臟で直接生成される一次胆汁 酸である chol 酸と chenodeoxychol 酸が優位になった と考えられる. 手術例の術中の腸液では二次胆汁酸であ る deoxychol 酸と lithochol 酸の増加が認められた. 閉 塞上部腸管において増殖した腸内細菌により分解を受け たためと考えられる ${ }^{677}$. 治療後の組成比の変化をみる と, 手術例では対照群の組成比に近いるのとなっている が, 非手術例では deoxychol 酸は隇少したままで chol 酸之 chenodeoxychol 酸優位の治療前に近い組成比であ り, それぞれ総胆汁酸濃度の変化と対応した変動であっ た.

通常胆汁酸は glycine または taurine と結合した抱合 胆汁酸として胆汁中に排泄される.そこでわれわれは， 抱合胆汁酸の glycine 抱合型之 taurine 抱合型の比, す なわち $\mathrm{G} / \mathrm{T}$ 比について検討したところ，腸閉塞症例で は対照群と比ぺて G/T 比は低下していた，著者ら ${ }^{8)}$ は胆 道手術後に外胆汁瘦としてT字管を留置した症例で手術 後数日間 $\mathrm{G} / \mathrm{T}$ 比の低下寸るのを観察しているが，これ と同様と考えられる. 胆汁酸の急速な喪失後肝缄におけ る代償作用としての胆汁酸合成が充進するまでに時間的 な遅延があるのか，あるいは肝蔵において glycine 抱 合能が低下するのか，今後さらに検討を要する問題であ る. 治療後の G/T 比の変化についてみると, 手術例も 非手術例も治療後上昇した.これは治療前に喪失した胆 汁酸を代償するために肝臓に拈ける胆汁酸合成が充進 し，肝臓内で利用できる taurine 貯蔵が少ないために生 体内で pool size の大きいglycine と抱合した胆汁酸が 優位となり $\mathrm{G} / \mathrm{T}$ 比が上昇したと考えられる 。著者らは
前述の T字管留置症例のその後の释過中に ${ }^{8)}$ ，また，回 腸結腸吻合症例において ${ }^{(0)}, \mathbf{G} / \mathbf{T}$ 比の上昇を観察してい るが，同様の機序によると考えられる.

腸閉塞症例の腸液中の細菌検索を行ったが, 手術例も 非手術例孔治療前には75 50\%に $10^{5} / \mathrm{ml}$ 以上の腸内細 菌の増殖が認められた．腸閉塞症における晹内細菌の意 義に関しては，古くよりその死因とは関係で数多くの研 究が双られ" 症における腸内細菌の増殖に関しては詳紐な報告をして いる. 治療後の変化についてみると, 手術例も非手術例 む $20 \sim 27 \%$ 症例に $10^{5} / \mathrm{ml}$ 以下の細菌が検出されたの みで細菌の検出率は低下した。これは腸管の閉塞解除に より腸内容が停滞しなくなったためと考えられる.

小腸内は通常蠕動運動, 胆汁酸の存在 ${ }^{14)}$, Bauhin 升 の機能等により比較的無菌状態に保たれており ${ }^{15)}$, 遊離 胆汁酸は検出されない. Northfield ら ${ }^{16)}$ は, 腸内細菌の 過利増殖の診断のため小腸液中の遊離胆汁酸の有無を検 索することが簡便かつ有用な方法であると述べている. 今回の検索症例では手術例の $44 \%$, 非手術例の73\%に遊 離胆汁酸が検出された. 腸閉塞症では前述のように増殖 した腸内細菌により抱合䏣汁酸が脱抱合 ${ }^{61{ }^{17}}$ されて遊離 胆汁酸が検出されるに至ったと考えられる. 治療後の遊 離胆汁酸の検出率の変化についてみると, 手術例では 9\%に減少したが, 非手術例では69\%と軽度減少した のみで高值が持続した. 腸内細菌の検索では治療後に は手術例子非手術例む細菌の検出率は低下しており, 両 者間に一致をみなかった，著者らはすでに，腸閉塞症例 に glycine-1-14C-cholic acid を経口投与して呼気中の ${ }^{14} \mathrm{CO}_{2}$ を経時的に測定し報告した ${ }^{18) 19)}$ 。この成績による と, 治療前には投与した標識同位元素の $21.4 \pm 6.44 \%$ が 呼気中に排出されるのに対して治療後には2.65士1.73\% であった.これは脱抱合によって生じた glycine-1- ${ }^{14} \mathrm{C}$ またはその代謝産物が腸管より吸収され，さらに代謝さ れて呼気中に排出された ${ }^{14} \mathrm{CO}_{2}$ を測定していれるので, 実際にはこれ以上の脱抱合が起っていると推測され，今 回の検索と同様の傾向を示したと考えられる. 呼気デ ト法では治療後に脱抱合率は低下していた.

腸閉塞時閉塞腸管内でこのように種々の変化を受けて 停滞している胆汁酸は, 松倉 ${ }^{1)}$, 恩田 ${ }^{2)} ら の$ 報告のよ5 に生体の防禦作用を有するが，一方 Wingate $5^{20)}$ の報 告のように, 腸管腔における水分, 電解質の吸収を阻害 する作用をもち, 腸閉塞時には腸管内の液体貯留の一因 となっていると考えられる. 腸閉塞症の病態, 特に閉塞 
腸管内に拈汁る胆汁酸の機能の解明が待たれる.

\section{結 語}

非絞扼性腸閉塞症例 42 例を対象とし，手術的あるいは 非手術的治療前後の腸液中の胆汁酸組成を薄層扣よびガ スクロマトグラフィー法で分析し検討を加え，以下のよ らな所見を得た。

(1) 晹閉塞症例の抱合胆汁酸 $\mathrm{G} / \mathrm{T}$ 比は低下したが, 治寮後には上昇した。

(2) 遊離胆汁酸の検出率は，手術例で術前44\%であ ったが，術後 $9 \%$ と減少した. 非手術例では治㞠例73 $\%$, 治療後 $69 \%$ と高い倹出率を呈した.

(3) 総胆汁酸濃度は著明に減少した。手術例では術後 飞急速な改善がみられた。

(4) 胆汁酸分画の組成比では, deoxychol 酸の減少が 著明であった，手術例の術中の腸夜では二次胆汁酸であ る deoxychol 酸と lithochol 酸の增加が認められ, 術後 には対照群の組成比に近い值を呈した，非手術的治療後 は治療前に近い值を呈した。

(5) 細菌検索では，手術例の術前に75\%の腸液に，非 手術的治療前に $50 \%$ の腸液に $10^{5} / \mathrm{ml}$ 以上の細菌増殖が 認められたが，それぞれ治療後には $10^{5} / \mathrm{ml}$ 以下に減少 した.

６）腸閉塞症例の腸液中の胆汁酸分析により，晹管の 閉塞状態や治療後の回復状況を観察するための重要な情 報が得られる。

本論文の要旨の一部は, 第10回日本消化器外科学会総 会(1977. 7. 神戸), 第78回日本外科学会総会(1978．4. 福岡)で発表した。

\section{文献}

1) 松倉三郎：イレウス時に拈ける胆计の病態生理 学的意義. 日本外科学大系, 小腸結腸 (III) 36 C, 109-120, 中山書店, 東京, 1971 .

2) 恩田昌彦：イレウスの研究一特汇胆汁の病態生 理学的意義を中心として一, 日外会誌, 68 : 237-258, 1967.

3) Gänshirt, H., et al.: Untersuchung zur quantitativen Auswertung der Dünnschichitchromatographie. 2. Mitteilung: Trennung und Bestimmung von Gallensäuren. Arzneimittel-Forsch., 10: 943—947, 1960.

4) Hofmann, A.F.: Thin-layer adsorption chromatography of free and conjugated bile acids on silicic acid. J. Lip. Res., 3: 127-128,
1962.

5) 大川 博汪か: Ursodeoxycholic acid の胆汁分 泌ならびに胆汁中成分に対する影響，基礎と臨 床, $10: 40-56,1976$.

6) Hill, M.J., et al.: Degradation of bile salts by human intestinal bacteria. Gut, 9: 22-27, 1968.

7) Norman, A., et al.: In vitro formation of deoxycholic and lithocholic acid by human intestinal microorganisms. Proc. Soc. Exptl. Biol. Med., 110: 552-555, 1962.

8) 石黑直樹汪か：胆道手術例に招ける胆汁中の胆 汁酸組成の変動。日消外会誌, 10：666-671, 1977.

9) Garbutt, J.T., et al.: Increased ratio of glycine- to taurine-conjugated bile salts in patients with ileal disorders. Gastroenterology, 56: $711-720,1969$.

10）石黒直樹 か：回晹結腸吻合症例 0 胆汁酸代 謝. 日消誌, $76: 1652-1659,1979$.

11）松倉三郎ほか：イレウス死因と腸内細菌一とく K大腸菌群一. 臨床外科, $21: 39-47,1966$.

12）岩間昭世：イレウスの死因，々くに細菌性因子 に関する臨床的ならびに実験的研究。日外会 誌, 76 ： 405-419, 1975.

13) Sykes, P.A., et al.: Alterations in small-bowel microflora in acute intestinal obstruction. J. Med. Microbiol., 9: 13-21, 1976.

14) Binder, H.J., et al.: Bile acid inhibition of intestinal anaerobic organisms. Am. J. Clin. Nutr., 28: 119-125, 1975.

15) Drasar, B.S., et al.: Studies on the intestinal flora. I. The bacterial flora of the gastrointestinal tract in healthy and achlorhydric persons. Gastroenterology, 56: 71-79, 1969.

16) Northfield, T.C., et al.: Value of small intestinal bile acid analysis in the diagnosis of the stagnant loop syndrome. Gut, 14: 341-347, 1973.

17）進藤邦彦：腸内細菌による抱合胆计酸分解作用 について，日消誌，70：1311-1319，1973.

18）福島恒男注か：腸閉塞症に求ける胆汁酸脱抱合 能の検討。日消誌, $73: 1358-1365,1976$.

19) Fukushima, T., et al.: Bile acid deconjugation in intestinal obstruction studied by breath test. Jap. J. Surg., 7: 73-81, 1977.

20) Wingate, D.L., et al.: Effect of glycine-conjugated bile acids with and without lecithin on water and glucose absorption in perfused human jejunum. J. Clin. Invest., 52: 12301236, 1973. 